\title{
Edgar Allan Poe, Machado de Assis e Julio Cortázar: três visões do conto em conjunção Roxana Guadalupe Herrera Alvarez*
}

\begin{abstract}
Resumo:
A partir do ensaio "Kafka y sus precursores", de Jorge Luis Borges (1899-1986), faz-se uma incursão pelo terreno do conto, relacionando as visões que Edgar Allan Poe (1809-1849), Machado de Assis (1839-1908) e Julio Cortázar (19141984) possuem sobre esse gênero. Propõe-se uma possível conexão entre os três escritores, considerados mestres do conto, pela via da proposta do ensaio borgeano, destacando as similaridades dos enfoques que pautam a elaboração artística dos contos dos três autores. Dá-se destaque à relação comprovada entre Poe e Machado de Assis e entre Poe e Cortázar, expondo a possibilidade de pensar também numa relação estreita entre Machado de Assis e Cortázar.
\end{abstract}

\section{Palavras-chave:}

Conto, Literatura Comparada, Allan Poe, Borges, Cortázar

\section{Precursores: uma proposta borgeana}

Jorge Luis Borges, em seu ensaio "Kakfa y sus precursores" (BORGES, 2007, p. 162-166), admitiu considerar Kafka um escritor singular. No entanto, com o passar do tempo, foi percebendo sua capacidade de reconhecer a voz do escritor em textos de diversas épocas, gêneros e latitudes. Esse exercício de reconhecimento, sem dúvida, estabelece a possibilidade de pensar a literatura como um amplo campo de inter-relações mediadas por parentescos nem sempre óbvios. Borges continua seu ensaio citando alguns exemplos dos textos relacionados com Kafka, seis ao todo, em ordem cronológica: o primeiro se refere ao paradoxo de Zeno contra o movimento; o segundo alude a um texto chinês sobre o unicórnio; o terceiro faz menção a um texto de Lowrie que recolhe duas parábolas de Kierkegaard; o quarto é um poema de Browning intitulado Fears and Scruples; o quinto e o sexto são dois contos, um trata da reclusão na terra natal e o outro, de uma viagem que nunca se completa.

\footnotetext{
* Doutora em Teoria da Literatura, Departamento de Letras Modernas IBILCE/UNESP/CSJRP.
} 
Borges afirma que os heterogêneos exemplos recolhidos por ele guardam com Kafka e com a obra kafkiana uma estreita semelhança sem, contudo, esses exemplos guardarem entre si a mesma relação de semelhança. Eis aqui o ponto mais importante apontado por Borges:

Si no me equivoco, las heterogéneas piezas que he enumerado se parecen a Kafka; si no me equivoco, no todas se parecen entre sí. Este último hecho es el más significativo. En cada uno de esos textos está la idiosincrasia de Kafka, en grado mayor o menor, pero si Kafka no hubiera escrito, no la percibiríamos; vale decir, no existiría. (Idem, p. 165-166)

Borges recolhe a questão central do seu ensaio nessas linhas: se Kafka não tivesse produzido seus escritos, não seria possível reunir os seis textos tão díspares citados por Borges. Dessa forma, é possível afirmar que Borges estabelece um princípio bastante simples, talvez óbvio, mas deveras perturbador. O escritor determina seus precursores. É o olhar retrospectivo e não o prospectivo que determina a relação entre escritores. Logo, as obras situadas em outros tempos e noutras culturas e línguas se congregam ao redor da obra de um determinado escritor graças ao poder de um ato consciente de leitura, cuja tarefa é revelar identidades esquivas. Essa afirmação está diretamente relacionada com as primeiras linhas do ensaio de Borges: "Yo premedité alguna vez un examen de los precursores de Kafka. A éste, al principio, lo pensé tan singular como el fénix de las alabanzas retóricas; a poco de frecuentarlo, creí reconocer su voz, o sus hábitos, en textos de diversas literaturas y de diversas épocas" (Idem, p. 162). Como é possível apreciar nas palavras do autor argentino, o ato de leitura, "o exame minucioso" revelam conexões imprevisíveis. E o mais importante: nem sempre o escritor está consciente da relação que sua obra guarda com textos de diversas culturas, épocas e línguas. Nem é preciso. Essa tarefa de juntar as peças dessa relação ignorada pelo escritor cabe ao leitor. Ele vai congregando e colecionando as semelhanças e os ecos de idiossincrasias latentes até construir um mapa de coordenadas improváveis. Cabe perguntar: como método, qual o valor de um olhar tão vasto como o de Borges?

Sem dúvida, a Literatura Comparada estabelece uma série de princípios úteis para estudar um dado conjunto de textos sob determinados propósitos. Um desses objetivos poderia ser estabelecer as influências que agem sobre um escritor ou uma obra (Cf. GUILLÉN, 1994). No entanto, a influência, para ser um conceito passível de aplicação, precisa do estudioso uma aferição palpável 
do fato. Isso diz respeito à identificação inequívoca de uma dada influência a partir da existência de uma citação explícita de uma obra em outra; pode ser a confissão direta do escritor, que em seus próprios textos admite se identificar com determinados autores e obras; também pode ser a constatação, por meio da consulta de documentos históricos, de que um determinado conjunto de idéias ou obras ditou os rumos da produção de um conjunto de textos. Nesses casos, a influência não deixa de contar com um fato capaz de ser invocado quando é preciso provar as relações entre textos ou autores. Contudo, é inegável que a influência é um conceito volátil mesmo amparado e cercado pelas balizas dos estudos da Literatura Comparada. Quando a determinação da influência não conta com provas concretas talvez o comparatista se sinta inclinado a rejeitar uma provável conexão entre obras e autores precisamente porque falta a prova material, tão cara às abordagens científicas.

A partir do impasse que se cria ao não se aceitar, dentro do campo da pesquisa, uma conexão entre obras e autores estabelecida pela mera intuição, o ensaio de Borges proporciona uma opção forjada no âmbito da própria arte. O pensamento de Borges, no ensaio em pauta, volta-se em direção à possibilidade de considerar a literatura um fenômeno ininterrupto, não demarcado nem por autores nem por escolas. ${ }^{1}$ Nesse grande e único texto, produzido e animado por um só e único espírito, todos os textos, em suma, se encontram.

Não é inoportuno dizer que essa idéia tão vasta, mas extremamente coerente, procede de um olhar ancorado na Arte. É inegável que um escritor vê a literatura de uma perspectiva distinta da do estudioso da literatura. Um artista, quando analisa seu campo artístico, é capaz de apresentar perspectivas assentadas em sua experiência e, por conseguinte, muitas vezes as perguntas são respondidas com afirmações que não se adaptam aos caminhos traçados pelos princípios de uma dada ciência. Para um estudioso da literatura, a afirmação de que a totalidade das obras literárias constitui um único texto escrito por uma única mão poderia soar tão radical ao ponto de invalidar as abordagens classificatórias de literaturas nacionais, movimentos de época e todos os conceitos organizadores de textos e autores, segundo a lógica do tempo. Mas sempre há como invocar a linha que separa a arte do seu estudo para impedir o colapso.

Voltando ao pensamento de Borges sobre Kafka e seus precursores, constata-se que essa perspectiva borgeana, contrária ao que num primeiro momento se

\footnotetext{
${ }^{1} \mathrm{Em}$ seu ensaio "A flor de Coleridge", Borges abole os conceitos de autoria e de textos isolados para condensar tudo num só espírito deflagrador do fenômeno literário, expresso num só grande e ininterrupto texto ( $v$. bibliografia).
} 
poderia esperar da tarefa dos estudos literários, provoca uma reação incômoda. Se os precursores são escolhidos pelo próprio texto gerado pelo escritor, e se esses precursores podem ser identificados pela leitura atenta, isso significa admitir que a literatura não pode ser apreciada em seu desenvolvimento estritamente linear e cronológico. Seria preciso supor que a literatura devesse ser apreciada como um fenômeno em que as chamadas influências não são sempre explícitas. Isso estabelece o desafio de abandonar o terreno das influências confessadas por um dado escritor para empreender a tarefa de estabelecer relações entre literaturas muito diversas no tempo e nas geografias sem um antecedente a uni-las. Também exigiria do pesquisador dispensar as provas materiais da influência - a determinação das leituras realizadas pelo escritor objeto de estudo e documentadas em diversos escritos; a tarefa de vasculhar os textos do escritor à procura de uma frase específica retirada de uma obra; a confissão de que há um mestre etc.- para empreender um caminho íngreme, alumiado somente pela fraca luz da idéia borgeana.

Sem dúvida, isso levaria, ainda, a um caminho bastante radical: em última instância, todos os textos literários estão profundamente relacionados entre si. Além disso, Borges afirma em seu ensaio que, no caso do poema de Browning, os versos prenunciam os escritos de Kafka, mas também é verdade que a existência dos escritos de Kafka possibilita uma singular leitura do poema de Browning. O poema de Browning não era lido em sua época do mesmo modo que se lê hoje depois de ter lido as obras de Kafka. Nesse sentido, Borges observa que a tarefa de todo escritor modifica a concepção de passado e também modificará a do futuro (BORGES, 2007, p. 166). E ainda, para obscurecer mais, Borges afirma que as primeiras obras de Kafka são menos precursoras da obra kafkiana do que os textos citados como precursores! Desse modo, encontram-se os grandes temas kafkianos disseminados na literatura de variadas épocas e lugares e não necessariamente nos primeiros escritos desse autor. Assim, o conceito de evolução também é questionado. Não há evolução sem que se julgue existir nos primeiros escritos de um autor as sementes do que na maturidade se revelará um grande tema ou uma técnica eficiente. Evolução, nesse sentido, é, também, um conceito precário, pois há autores rompendo com seus primórdios e lançando-se a uma plenitude nunca antes prenunciada.

As reflexões advindas do ensaio de Borges estabelecem, sem dúvida, um novo percurso na compreensão das relações entre os diversos escritos constitutivos do grande acervo da literatura, entendida como o conjunto de textos vistos 
além das delimitações das distintas épocas e dos diversos países e línguas. Nesse sentido, um escritor de uma dada nação poderia ter um precursor, sem o (re)conhecer, numa outra fronteira, a se expressar numa outra língua e numa outra época. Essa sintonia poderia estar ancorada nas reminiscências do estilo, das idiossincrasias, do tom, da atmosfera, dos temas, das personagens e somente se revelaria pelo poder de evocação de um leitor atento, como Borges deixa entrever.

Seria lícito indagar se essa evocação que correlaciona textos e autores de épocas e nações díspares, sem sinais explícitos desse pressuposto relacionamento, poderia se tornar um método eficaz para abordagem e estudo da literatura. Sim e não. A resposta afirmativa estaria amparada no próprio caráter do objeto estudado, como Borges parece elucidar. As obras literárias produzidas numa dada época extrapolam os limites impostos pelo momento, pelos costumes coetâneos e adquirem, na leitura empreendida em outras épocas, significações - se não radicalmente diversas das de seu tempo, pelo menos amplificadas pelo novo contexto temporal que as acolhe. Disso se depreende que o estudo de um texto literário, alicerçado em abordagens históricas ou sociológicas, com o intuito de compreender os costumes e motivações próprios de uma dada época, não está excluído dessa perspectiva de leitura, uma vez que a compreensão do texto propõe um trabalho de reunificação de perspectivas, tanto das que se mantêm ligadas ao tempo da concepção artística do texto, quanto às da época em que a nova leitura é realizada. Esses fios temporais se superpõem e enredam permitindo verificar que um texto de épocas passadas pode estar presente em tom, atmosfera, idiossincrasias num dado texto atual. E esse diálogo é possível graças a um ponto em comum entre escritores: a possessão de um olhar que, fixando-se nos objetos de seu tempo, é capaz de dotar esses objetos de uma ordenação capaz de fazer sentido também ou somente no futuro. E esse fazer sentido não corresponde, necessariamente, a entender as significações completas da ordenação original, também diz respeito ao fato de os objetos do passado continuarem existindo, mesmo com outras roupagens, para o olhar de leitores de épocas futuras. Isso tem a ver com o que se costuma dizer da literatura: é possuidora de um sentido universal do humano.

Por outro lado, a resposta negativa à questão acima exposta, relaciona-se com a falta de provas materiais: citações, alusões, paródias, paráfrases, plágios e demais. Esses vestígios explícitos, levantados dentro de um dado texto, indicam claros caminhos em direção à relação inequívoca entre autores e textos de 
diversas procedências. Mas também limitam grandemente a possibilidade de estabelecer nexos entre obras a partir da percepção global de uma semelhança difusa, estabelecida em termos menos explícitos: o tom da composição de um conto, por exemplo.

\section{$O$ conto em perspectiva}

É lugar-comum dos estudos literários considerar o conto um produto de origem popular, de veiculação oral. Afirma-se que muitas de suas características advêm, precisamente, desse tom descontraído das narrativas movidas pelo sabor do momento. Um relato oral aduna o tom do contador de histórias e o cenário do qual se pode extrair boa parte do interesse da narrativa. Então, pensar o conto nesses termos permite supor que todos os contos têm uma matriz comum, guardada e garantida pelas origens incertas do gênero. Nesse sentido, seria fácil e apropriado dizer que o primeiro contista, cuja identidade talvez nunca seja revelada é, obrigatoriamente, precursor de toda a linhagem de contistas conhecidos até hoje. E essa afirmação não carece de lógica, pelo contrário, tem o mérito de dar ao conto um aspecto coeso e quase eterno (cf. MARTÍN TAFFAREL, 2001).

No entanto, é difícil sustentar, mesmo dentro de um gênero como o conto, relações tão amplas de aproximação entre autores e textos. Aqui entra outro lugar-comum dos estudos literários, o que diz respeito à visão da literatura organizada em movimentos de época, com um conjunto de características próprias cuja função é delimitar estilos. Por meio dessa visão, cria-se um pequeno empecilho à idéia de um precursor comum para todos os contistas, pois havendo distintos estilos de época, marcados por características próprias, como seria possível falar de um precursor para todos eles?

Considera-se que um determinado movimento literário visto em seu conjunto, caracteriza-se por manter a coesão por meio de um grupo de escritores que se expressa aderindo a uma determinada convenção, a qual tornará reconhecível a produção desses artistas como dentro de um dado movimento e os fará ser excluídos de outro. Consta que essa tentativa delimitadora pode ser amplamente questionada, como o provam os trabalhos mais acurados sobre autores inclassificáveis. ${ }^{2}$ Então, a objeção à possibilidade de estabelecer um precursor, acima das fronteiras dos movimentos literários, não se sustentaria, principalmente porque o conto poderia ser apreciado mais como estrutura

\footnotetext{
2 Machado de Assis é um caso atípico na história da literatura brasileira. Há dificuldades em considerá-lo ora romântico, ora realista, segundo as épocas e estilo de sua produção. É um escritor que parece não se adequar às características atribuídas ao Romantismo e ao Realismo.
} 
composicional, cujas características, nesse nível de apreciação, poderiam ser citadas em seu conjunto, e menos como variação ao sabor dos estilos de época. Desse modo, as afinidades textuais revelar-se-iam além das fronteiras dos movimentos literários, além das convenções literárias.

Voltando à proposta do ensaio de Borges, ao afinar as fronteiras demarcadoras dos estilos de época, seria possível ver nos contos cultivados nesses distintos tempos, países e línguas um incessante diálogo em busca de uma forma comum. Porém, pode-se pensar que a idéia de manter um gênero como norteador, neste caso, o conto, anulará a ampla visão borgeana que dá à literatura uma natureza quase infindável. No entanto, a delimitação proposta pelos gêneros está compreendida também nessa vasta apreciação borgeana da literatura. E ao tomar o conto como fio condutor, será possível estabelecer um canal de comunicação entre três autores, de épocas, línguas e geografias diversas: o estadunidense Edgar Allan Poe (1809-1849), o brasileiro Joaquim Maria Machado de Assis (1839-1908) e o argentino Julio Cortázar (1914-1984). Poe é considerado um dos mestres do conto moderno. Isso supõe dizer que o conto, antes do século XIX, havia sido, em certo sentido, eclipsado várias vezes por outros gêneros. Tomando o ramo hispânico do gênero - que serve de guia para imaginar o acontecido em outros contextos - , das suas origens milenares, passando pela Idade Média, mais especificamente nos antigos territórios que hoje congregam a Espanha, houve o cultivo de um tipo de conto breve que servia a interesses elitistas e cuja finalidade eminentemente didática se destacava como marca registrada. Esses relatos recebiam durante essa época nomes variados: eixemplo, fábula, apólogo, novela. Vejam-se os textos recolhidos em El Conde Lucanor, do infante Don Juan Manuel, para citar um exemplo consagrado. Tem-se, durante a Renascença, o cultivo de um tipo de relato mais extenso, também ligado aos valores religiosos, filosóficos e morais segundo a perspectiva da época. As Novelas ejemplares, de Miguel de Cervantes, obra publicada no século XV, é um exemplo bem acabado de conto. Já no Século das Luzes houve uma série de realizações nesse campo também, porém deixadas em segundo plano pelos ensaios, as fábulas e a poesia (cf. OMIL; PIEROLA, s.d.). Com a chegada do século XIX, segundo as periodizações literárias aceitas, passam a conviver e a se suceder nesse século o Romantismo, o Naturalismo, o Realismo, para citar os estilos de época mais lembrados. Cada um desses movimentos apresenta um caráter particular de realizações artísticas, como recolhem tantos manuais de literatura. E é nesse século que o conto volta a se revelar um gênero importante. 


\section{Julio Cortázar e Edgar Allan Poe}

Poe nasceu e viveu nos primeiros anos do século XIX nos Estados Unidos e, segundo a biografia elaborada pelo escritor argentino Julio Cortázar - como introdução a um volume de contos do escritor norte-americano traduzidos para o espanhol pelo próprio Cortázar-, Poe conviveu com um entorno vulgar e sua capacidade artística foi, por muitos, admirada, mas também ignorada por outros tantos. Em suma, Cortázar sustenta que Poe era um deslocado, um homem sem possibilidade de encontrar eco paras suas inquietações intelectuais e artísticas em seu meio. Sem dúvida, Poe, circundado pela aura de artista incompreendido, como tem sido plasmado na história da literatura, recebe, como foi apontado acima, o título de mestre do conto moderno, junto com Maupassant e Tchekov. E a categoria de mestre foi atingida por ele graças a um conjunto de poemas e contos admiravelmente construídos e a uma série de ensaios voltados à criação e elaboração de obras literárias e ao comentário sagaz de obras de seus contemporâneos (cf. CORTÁZAR, 1993, p. 103-146).

As reflexões de Poe sobre a literatura são interessantes porque as alicerça numa perspectiva intelectual do ato de escrever. Munido de um talento lógico colocado ao serviço da sua arte, Poe soube descrever e dissecar o percurso de sua mente na arquitetura de um longo e lúgubre poema intitulado "O corvo", cujo desvendamento, no que diz respeito a sua criação e elaboração, é referido minuciosamente no conhecido ensaio "A Filosofia da composição". ${ }^{3}$ Mesmo que tal ensaio dedique a totalidade das reflexões à poesia e à feitura do poema, não escapa que as idéias expostas com uma precisão surpreendente possam também servir para refletir sobre outro gênero que, para Cortázar, guarda profunda relação com o poema: o conto.

Em seu ensaio "A Filosofia da composição", Poe (1999, p. 101-114) afirma que o poeta deve buscar para sua obra um grande tema humano e um tom adequado para tratar esse tema; deve escolher o ritmo da linguagem, o qual deve espelhar o tom e o tema; deve prever o clímax, que poderá coincidir com o final do poema para poder construir as demais partes ao redor desse ponto alto que se deseja atingir. Como se vê, Poe afirma que a escolha deliberada de um dado efeito que se deseja impor sobre o leitor deve nortear todo o trabalho de construção do poema. Sem essa intencionalidade não é possível encontrar os elementos adequados para compor o texto.

\footnotetext{
3 Cortázar observa, no texto sobre Poe, que o escritor norte-americano certamente criou uma espécie de jogo com o qual pretendia convencer o leitor de seu ensaio que tivera domínio absoluto no ato de compor um poema extenso. Cortázar afirma que muito escapa da consciência de todo escritor com relação à composição de suas obras.
} 
Um dos grandes méritos de Cortázar é ter interpretado e trazido as idéias de Poe para o âmbito de sua própria produção ensaística e contística. O escritor argentino recolhe em dois conhecidos ensaios uma teoria sobre o conto espelhada em Poe: "Alguns aspectos do conto" (CORTÁZAR, 1993, p. 147-163) e "Do conto breve e seus arredores" (Idem, p. 227-237). O escritor argentino elaborou uma teoria do conto a partir dos conceitos de tensão e intensidade, descritos no ensaio "Alguns aspectos do conto". Esses princípios nascem de uma leitura eficaz e sensível dos escritos literários e críticos de Poe. Sem dúvida, tensão e intensidade são conceitos globais que devem ser compreendidos a partir da leitura completa de um dado conto. Tensão e intensidade resultam da necessária somatória de todos os elementos utilizados para estruturar um conto e dizem respeito ao tema e ao trabalho preciso com a linguagem. A escolha do tema, como diz Cortázar, é muito importante porque ligado a ele surgem as palavras precisas que vão construir o conto. A tensão procede da relação de economia presente no conto, de tal modo que seus elementos não sobrem nem faltem. Isso redunda num cuidado com a elaboração de cada frase e as digressões nunca são contempladas. A intensidade procede de um trabalho na vertical, como diz Cortázar, num processo de aprofundamento até atingir uma força capaz de atingir o leitor em cheio, do mesmo modo como o escritor o foi por conta da elaboração do conto.

O trabalho de análise profunda da obra de Poe foi empreendido por Cortázar quando fez a tradução dos contos do escritor norte-americano. Sem dúvida, a tarefa de verter para o espanhol as narrativas de Poe causou em Cortázar a impressão de estar apreciando o tecido pelo avesso. Penetrar na máquina de elaboração dos contos de Poe obrigou o escritor argentino a percorrer um caminho de criação também, pois ao traduzir uma obra literária, é inegável que a linguagem em que se traduz deverá perseguir os sentidos poéticos da obra original. Esse trabalho meticuloso de tradução revelou para Cortázar possibilidades criativas reveladas na forma de seus contos mais célebres: "Casa tomada", a história de dois irmãos coagidos a deixar sua casa por uma força inexplicável é, sem dúvida, um belo diálogo intertextual com "A queda do solar de Usher"; "Manuscrito hallado en un bolsillo" [Manuscrito encontrado num bolso] retoma uma viagem sem retorno empreendida como o protagonista de "Manuscrito encontrado numa garrafa". Esses dois exemplos contam com o reconhecimento de que Poe foi uma das mais atuantes e reconhecidas influências de Cortázar. Um leitor desavisado, que por ventura lesse primeiro um desses contos de Cortázar e à continuação um dos de Poe, e nada soubesse 
de estudos literários nem sobre ordenação cronológica, poderia pensar que o argentino influenciou o norte-americano, por uma questão de ingenuidade temporal, talvez. Esse equívoco serviria para nos alertar sobre a pretensa circularidade do tempo e dos fenômenos, como já disse certa vez Borges em seu conto "Las ruinas circulares" [As ruínas circulares]. Obviamente, numa percepção dessa natureza, não há necessidade de situar o passado e o futuro, pois se encontram coexistindo sempre num dado ponto. Retomando o ensaio borgeano, pode-se perceber que se o escritor permite estabelecer seus precursores, não de forma voluntária, mas por afinidades percebidas entre suas obras e as de seus predecessores graças ao trabalho de leitura, provavelmente poder-se-ia estabelecer uma afinidade entre Julio Cortázar e Machado de Assis. Seria possível dizer que Machado de Assis é, em certo sentido, precursor de Julio Cortázar.

\section{Machado de Assis e Edgar Allan Poe}

É conhecido o prólogo do volume machadiano de contos intitulado Várias histórias. Nele, o escritor brasileiro aprecia os contos de Poe e os destaca como sendo "entre os primeiros escritos da América." (MACHADO DE ASSIS, 1992, p. 476). Também é sabido que Machado de Assis traduziu o poema "O corvo". Nesse labor analítico e delicado de tradução, houve um processo análogo ao vivenciado por Cortázar. Traduzir propiciou a Machado de Assis um exercício literário de apreciação crítica, um esforço para encontrar no próprio idioma afinidades de ritmo frasal e intelectual com a obra de Poe. Assim, a tarefa tradutória deve ter contribuído para o desvendamento de certos procedimentos da linguagem do escritor estadunidense que não escaparam ao olhar atento do escritor brasileiro. ${ }^{4}$

Voltando aos contos, há dois casos particulares na prosa de Machado de Assis que vale a pena citar, destacando a relação com os escritos de Poe. Os contos "O enfermeiro", angustiante releitura de "O coração denunciador", de Poe, sem, contudo, dar aos sentimentos de culpa e remorso um lugar de destaque, como no conto do norte-americano, e "A causa secreta" que espelha uma situação de sadismo invertido. O Fortunato machadiano é o torturador. No conto "O barril de Amontillado", de Poe, Fortunato é vitimado pela inveja de um algoz sem nome. Essas duas narrativas de Machado de Assis recolhem, sem dúvida, um diálogo intertextual com os contos de Poe. Há um processo de estilização mais evidente

\footnotetext{
${ }^{4}$ Sobre a importância do ato de traduzir, consulte-se o ensaio de Jorge Luis Borges intitulado "Las versiones homéricas" e o ensaio de Walter Benjamin "A tarefa-renúncia do tradutor" ( $v$. Bibliografia).
} 
em "A causa secreta", principalmente porque a reminiscência do conto de Poe está no nome de uma das personagens, Fortunato que, de vítima no conto de Poe, passa a algoz no conto machadiano, como já foi apontado. No outro conto, o enfermeiro vê esmorecer com o passar do tempo o remorso e acaba eximido de qualquer culpa pelas circunstâncias. Já no conto de Poe, a personagem admite sua loucura e no esforço de ocultar o crime, tentando agir de modo normal e inocente, incrimina-se e confessa o assassinato aos brados. Os narradores-protagonistas desses dois contos têm em comum a necessidade de se explicar. A percepção do diálogo entre os contos de Machado de Assis e os de Poe $^{5}$ coloca em evidência uma afinidade intelectual que eclodirá numa possível relação entre o escritor brasileiro e Cortázar, como já se disse, pela via borgeana.

\section{Machado de Assis, precursor de Julio Cortázar}

Sabe-se que o escritor brasileiro admirava a obra de Poe. Logo, se Poe é admirado por Cortázar e Machado de Assis, é possível inferir a existência de uma relação de afinidade entre o escritor brasileiro e argentino, oriunda, não de um necessário contato de um com a obra do outro, mas de uma postura crítica face à criação artística e da abordagem de alguns temas. No caso específico do conto, Machado de Assis pode ser um legítimo precursor de Cortázar, num lato sentido borgeano. Principalmente porque, parafraseando Borges, se Cortázar não tivesse escrito seus contos, não seria possível encontrar ecos de sua perspectiva crítica e de alguns temas em contos de Machado de Assis. Logo, a perspectiva machadiana do conto encontra ecos na obra de Cortázar, dessa forma, o escritor argentino escolheu como seu precursor o escritor brasileiro, segundo a curiosa perspectiva borgeana.

Uma relação mais imediata entre as obras de Cortázar e Machado de Assis é a que aponta a utilização por parte de ambos de um narrador-defunto. No conto "Las babas del diablo", incluído no volume Las armas secretas, de Cortázar, o narrador, um fotógrafo, escreve olhando as nuvens que passam sobre sua desgraça, confessa sua condição de morto e passa a relatar as circunstâncias de seu decesso. ${ }^{6}$ Já o romance machadiano intitulado Memórias Póstumas de Brás

\footnotetext{
${ }^{5}$ Para obter mais informações sobre a relação entre os textos de Machado de Assis e de Edgar Allan Poe consulte-se a obra Machado de Assis: um escritor na capital dos trópicos, de Patrícia Lessa Flores da Cunha. Um estudo importante sobre a relação intertextual entre os dois autores. Oferece um estudo interessante de uma série de textos dos dois autores, do qual não consta a relação estabelecida entre os contos citados neste artigo.

6 No prólogo do volume Las armas secretas, de Julio Cortázar, Susana Jakfalvi observa que o narrador de "Las babas del diablo" , dada sua complexidade, já foi identificado com Michel, o
} 
Cubas apresenta um autor-narrador defunto que vai organizando suas lembranças ao sabor de uma consciência irônica, capaz de desvendar uma existência fútil. Esse expediente narrativo - um narrador que se confessa defunto- é uma semelhança que não escapa. No entanto, é inegável que cada escritor imprimiu uma vontade peculiar quando concebeu um narrador nessas condições. Na perspectiva dos estudos voltados à obra de Cortázar, o narradordefunto é inserido no fantástico ou no neofantástico, como quer o crítico argentino Jaime Alazraki. ${ }^{7}$ Nesse sentido, o narrador-defunto de Cortázar desestabiliza uma noção de real e propõe uma visão perturbadora, típica dos seus contos. Já o narrador-defunto machadiano nem sequer coloca em pauta a possibilidade de se deter em seu provável caráter fantástico. Desvia-se o foco do caráter surpreendente do narrador já estar morto e referir sua história e se aceita como parte inerente da narrativa, cujo tom é eminentemente irônico.

Talvez esse exemplo baste para expor um grau de aproximação entre Cortázar e Machado de Assis, dada a escolha de narradores em estreita afinidade. Contudo, há um ponto que demonstra uma afinidade muito maior entre o escritor argentino e o brasileiro. Trata-se da consciência crítica com que ambos empreenderam o ofício de escritor. Nesse ponto, será oportuno lembrar que tanto Cortázar quanto Machado de Assis tiveram em Poe um mestre. O conto, gênero difícil, assim designado pelo escritor brasileiro, foi cultivado pelos três artistas visando a excelência do gênero. Tal objetivo fica patente na proposta de elaboração dos textos literários desses autores. Para Poe, como se viu, uma composição literária perfeita persegue um propósito claro: planeja-se a obra a partir do efeito a ser obtido, não sem antes ter planejado cuidadosamente o epílogo. Para Cortázar, o conto precisa de uma clara noção de economia e harmonização entre os elementos que o constituem, de tal modo que possa impactar o leitor. Para Machado, o conto, produto contundente, ergue-se pela mão segura de um narrador, cujo olhar impregnado de certo desencanto pela vida, vai oferecendo caracteres desvendados ironicamente, os quais produzem no leitor ora o riso agitado, ora o riso melancólico. Sem dúvida, os três escritores optam pela consecução do impacto como a mais habilidosa forma de capturar e golpear o leitor. Há nos três a construção medida, cujo resultado é

fotógrafo e tradutor que morreu e conta sua história, já foi apontado como a lente da máquina fotográfica, e já foi analisado como o próprio tempo (v. Bibliografia).

7 Jaime Alazraki, em seu ensaio "¿Qué es lo neofantástico?" aponta uma série de características que separam o neofantástico da concepção clássica de gênero fantástico. Insere Cortázar nesse novo gênero e depreende dos contos do escritor argentino muito do que caracteriza o neofantástico ( $v$. Bibliografia). 
um final impregnado de surpresa, seja pela via do estranho, como em Poe, pela do fantástico, como em Cortázar, pela da ironia, como em Machado.

Além da identificação existente entre os três escritores, no que diz respeito ao trabalho com a construção do conto, Cortázar e Machado de Assis podem, ainda, ser aproximados em termos da temática de alguns textos. Tome-se o texto cortazariano "Distante espejo" [Distante espelho], obra pouco conhecida e ausente das antologias mais comuns, e o conto machadiano "O espelho". No relato de Cortázar, há um narrador em primeira pessoa, também personagem, que se apresenta como ser arredio. É um professor interiorano, dado ao deleite da leitura. Na tarde do dia 15 de junho de um ano não definido, contrariando o costume cotidiano de permanecer fechado em seu quarto a tarde toda, é impelido a sair. Vai pelas ruas da cidade sentindo o calor do sol e, subitamente, afirma ter sido tomado por uma sensação que parece cindir corpo e alma. 0 corpo deseja ir por um determinado caminho e a alma, por outro. Empurrado por uma força estranha, abandona o projeto de ir até a praça do povoado e ruma em direção à casa de uma colega da escola. Toca a campainha insistentemente e se dá conta de que não há ninguém. Movido por algo incompreensível, entra na casa e percebe que está na pensão onde mora. Tudo é como na pensão. Reconhece a sala, os móveis e vê a porta do seu quarto. Entra e se vê a si mesmo lendo confortavelmente vestido. O horror paralisa o corpo do observador, que se percebe realizando todas as atividades habituais sem notar-se a si mesmo enquanto observador. O observado passa pelo observador como diante de um espelho bem conhecido, sem olhar a imagem diretamente. A dissociação dura até o momento em que o observador e o observado saem do quarto e vão até a rua. Ao voltar, já são um só ser e têm a certeza de terem entrado, dessa vez, na verdadeira pensão em que moram. Indescritível a sensação e o prenúncio da insônia. Dedica o tempo a gravar na escrivaninha suas iniciais: G. M. Fica acordado até o amanhecer e vai se deitar lembrando que terá aula às nove da manhã. Depois da aula, decide ir até a casa da colega da escola. Ela o recebe e ele entra receoso de encontrar a mobília e o quarto da pensão, mas tudo é diferente, está na casa da colega. Respira aliviado, mas, ao entrar na sala, tem a impressão de que entrará novamente em seu quarto da pensão. A impressão dura pouco, pois encontra móveis desconhecidos e não os dele. Porém, a sensação de alívio dura pouco. A colega da escola, ao mostrar a mobília da sala, não reprime um sentimento de desapontamento ao ver a escrivaninha rabiscada, talvez por obra dos netinhos. Ao chegar mais perto, o narrador-personagem encontra gravadas as iniciais G. 
M. Suas iniciais. Como é possível notar, o impacto e o efeito-surpresa do texto procedem do fato de ter havido uma espécie de superposição inexplicável de espaços e tempos, tudo captado por uma consciência que observa, fora e dentro de si. No entanto, também é possível pensar num simples acaso que pode ter gerado a existência de dois pares de iniciais, G.M., em duas escrivaninhas diferentes. Essa ambigüidade é capaz de instaurar uma dúvida que só faz aumentar o impacto do final do conto.

Já o conto machadiano "O espelho" narra uma surpreendente experiência vinculada à descoberta da própria identidade. O narrador refere a um grupo de amigos a experiência vivenciada em sua juventude: a descoberta de que há duas almas, uma que olha de dentro para fora e outra, de fora para dentro. Essa última é a alma exterior, que pode ser um espírito, um fluido, pessoas, uma operação, um objeto qualquer. Refere a época em que foi nomeado alferes da guarda nacional e como foi chamado por uma tia que pediu para vê-lo e que levasse a farda. No quarto destinado a ele, a tia mandou colocar um grande, velho e rico espelho. Tantas atenções recebidas fizeram o rapaz eliminar o homem para ceder espaço ao alferes. Sua alma exterior se identificava com tudo o que era próprio de seu posto e com os elogios recebidos. Um dia, estando sozinho na casa da tia, depois de dias sumido na mais completa solidão, decide se olhar no espelho. Tem a nítida sensação de se sentir cindido em dois e pensa ter visto sua imagem esfumaçada no reflexo do espelho. Agoniado com a sensação de incompletude refletida, decide vestir o uniforme e olhar-se no espelho. Contempla sua imagem completa e clara, sua alma exterior estava íntegra no espelho. Subitamente percebe que ao vestir o uniforme consegue se sentir completo e, desse modo, enfrenta a solidão ao longo de dias. Depois que a narrativa termina, o narrador escapole e deixa seus ouvintes surpresos.

É possível estabelecer uma relação entre os dois textos apresentados. Tanto o de Cortázar quanto o de Machado se debruçam sobre a problemática da identidade vista a partir de um confronto crucial. O momento decisivo vivenciado pelas personagens estabelece um percurso incômodo, pois revela que a sensação unívoca do indivíduo pode ser somente uma ilusão. Diante da possibilidade da cisão entre alma e corpo, como no texto de Cortázar, ou entre a alma interior e a exterior, como no conto de Machado, os narradores atualizam em suas narrativas o dilema humano, sintetizado em pares já conhecidos: ser ou parecer, estar acordado ou sonhar, viver ou morrer, ser ou não ser... Os corpos aparentemente sólidos, quando enfrentados aos seus respectivos 
reflexos, devolvem um simulacro cujo impacto sobre o observador revela a precariedade da capacidade perceptiva e, quiçá, a da própria certeza de existir coerentemente.

Como é possível notar, Machado de Assis e Cortázar tangenciam, em seus relatos, um grande tema humano tomando como fio condutor o espelho e seu reflexo. Tal coincidência no tratamento de um tema não deve surpreender, porque o espelho é um objeto cuja simbologia recolhe abundantes matizes nos variados contextos culturais. Segundo Chevalier e Gheerbrant (1989, p. 393396), o espelho é o símbolo da sabedoria e do conhecimento, também é utilizado para a arte da adivinhação. Considera-se, igualmente, como a alma, que é capaz de refletir a beleza ou a feiúra, mas não passivamente, pois a alma, enquanto instrumento puro, refletirá melhor e poderá se fundir com o que reflete, transformando-se.

Dessa forma, colocados juntos, os textos se iluminam mutuamente e o leitor é capaz de, ao modo da proposta borgeana, traçar interseções e rotas que propiciam o encontro entre a perspectiva machadiana e a cortazariana. Mas a afinidade não esta presente só no tratamento do tema, também é possível perceber o comprometimento, por parte dos dois autores, com a elaboração do conto. Ambas narrativas seguem um percurso que recolhe uma série de elementos postos a funcionar com o objetivo de conseguir um grande impacto final. No texto de Cortázar, a sequência de eventos se apóia numa aparente feição comum: a vida regrada de um professor interiorano e solitário se vê subitamente alterada num dia qualquer em que experimenta uma sensação de intranqüilidade a lançá-lo à rua, em busca de algo indefinido. Essa saída será o ponto de partida de uma experiência estranha: a cisão de alma e corpo. A partir desse dado intangível, só definido pela subjetividade da personagem, os eventos começam a criar um cenário inquietante que se revela perturbador, quando no final do relato, o narrador-personagem acredita reconhecer, na sala da colega da escola, as iniciais G. M. gravadas numa escrivaninha desconhecida. $O$ ato de gravar as iniciais foi executado por ele, sem dúvida, numa escrivaninha da pensão em que mora, mas como apareceram as letras num outro espaço físico? Já o conto de Machado de Assis vai se tecendo a partir da introdução de um narrador em terceira pessoa que cede a voz a uma personagem que relatará sua incomum experiência. Na juventude, sendo alferes, vai visitar uma tia e recebe atenções constantes, de tal modo que passa a se identificar profundamente com sua posição de alferes, esquecendo sua vida de antes. Um dia, enfrenta uma situação inusitada que é em si uma revelação: abandonado 
de todos e ao se contemplar no espelho, sua figura se esvai. Só quando se olha vestido de uniforme de alferes passa a se enxergar sólido e real. Desse modo, enfrenta a verdade dos fatos: a alma exterior pode ser capaz de sustentar a identidade de um ser. Tal revelação deixa sumidos na perplexidade seus ouvintes e também o leitor.

Como é possível apreciar, os desfechos dos contos propõem situações cuja compreensão dá ao leitor a capacidade de entender como a mobilização gradual dos elementos narrativos, no início, meio e fim da narrativa, teve o propósito de atingir o ponto alto, na forma de uma grande revelação. No conto de Cortázar, o desvendamento da precariedade do que é chamado de real. No conto de Machado de Assis, a incerteza da própria existência. O leitor, contundido pela revelação do grande tema dos contos, saboreia, após a leitura, uma sensação de desassossego. Nesse ponto, é oportuno assinalar que Poe, Machado de Assis e Cortázar pertencem à linhagem dos contistas devotados a desbaratar qualquer esperança e a pôr em constante dúvida toda e qualquer certeza que possa trazer um pouco de consolo e segurança diante das coisas intrincadas do mundo. O leitor que os escolhe e lê sabe de antemão as pontes que terá de cortar e as explicações às quais terá de renunciar.

\section{Poe, Machado de Assis e Cortázar: sintonias reveladoras}

Uma vez apreciada a possibilidade de descobrir afinidades entre Machado de Assis e Cortázar, pela via borgeana, será oportuno se referir à tríade de contistas, formada por Poe, Machado de Assis e Cortázar, como impulsionada por um mesmo ideal de realização artística. A sintonia percebida entre esses três mestres do conto seria tal qual o parentesco intuído por Borges em seu ensaio "Kafka y sus precursores": a obra de um determinado autor é capaz de mobilizar reminiscências na produção de outro escritor, pelo ato da leitura, mesmo que não tenham uma relação comprovada nem se reconheçam as influências. No caso da tríade em pauta, sem a existência de Poe, quiçá não seria possível pensar em aproximar Machado de Assis e Cortázar. O fato de o escritor brasileiro e o argentino terem reconhecido em Poe um grande mestre, esboça a possibilidade de encontrar afinidades entre os dois escritores latinoamericanos. Tais afinidades dizem respeito à postura crítica com a qual se dedicaram à tarefa de escrever e à adesão às idéias de Poe sobre a elaboração do conto, cingindo-se à consecução de um grande efeito ligado basicamente ao epílogo. Cortázar dedicou ensaios a essa temática, nos quais é possível notar a adesão às idéias de Poe. Vejam-se os já citados "Do conto breve e seus 
arredores" e "Alguns aspectos do conto". As breves alusões de Machado de Assis, na introdução de alguns volumes de contos, à obra de Poe e a magistral elaboração dos seus próprios contos, cuja leitura vai desvendando o engenhoso maquinismo posto em movimento em cada texto, revelam um trabalho de reflexão em parte motivado pelas idéias de Poe. Trata-se de um reconhecimento da obra do escritor estadunidense e de suas importantes realizações sem, contudo, deixar de dar às próprias obras uma marca singular.

Tal singularidade se faz mais patente ao se incursionar pelo campo do fantástico e do estranho, classificados como gêneros autônomos por Todorov (2003, p. 4763). Segundo a visão desse crítico, a contística de Poe dialoga basicamente com o estranho, pois, em muitos contos, há uma revelação que faz cair por terra a presunção da existência de um fenômeno sobrenatural. Há o desvendamento ou explicação racional dos fatos, antes tomados como espectrais. Veja-se o conto já citado "A queda do solar de Usher", no qual há o episódio da irmã do amigo do narrador-protagonista que parece ter ressuscitado, mas, na verdade, o que acontece é que a depositaram num nicho quando sofreu um ataque de catalepsia e, ao voltar a si, descobre ter sido posta dentro de um ataúde, consegue escapar e volta para se vingar do irmão. Esse gênero se revela ideal para ser moldado de acordo com as propostas de Poe, já que um dado efeito e um final contundente podem ser obtidos na elaboração de contos acordes com o gênero estranho ou fantástico. Por outro lado, será oportuno observar que não escapa a qualquer estudioso do gênero fantástico o fato de Machado de Assis, ao incursionar pelo gênero, preferir sacrificar a realização pura e simples de um relato fantástico para pôr o texto ao serviço de uma aparente tese moral, como no conto "Sem olhos", em que o adultério aparece punido de forma estarrecedora, ou para resvalar pelas fronteiras do grotesco e do irônico, como em "Um esqueleto". Já Cortázar preferia revolucionar o gênero fantástico não abrindo mão dos expedientes tradicionais do gênero com o objetivo de negá-los, revitalizá-los e atualizá-los. Prova disso é o já citado relato "Casa tomada", uma angustiante experiência motivada por uma presença nunca conhecida nem revelada e devotada a expulsar dois irmãos do lar. Nesse sentido, é muito difícil apontar afinidades entre Machado de Assis e Cortázar no terreno do fantástico, pois o cultivo desse gênero, possível via de estudo, mais parece afastar os dois escritores latino-americanos e não aproximá-los. Onde residiria, então, o território comum desses dois escritores? Como foi apontado acima, na consciência voltada à elaboração artística, no reconhecimento de que o conto é um gênero difícil porque visa à economia de meios, à obtenção de um grande 
efeito revelado basicamente no epílogo, à estrutura bem concebida e executada, segundo os ditames de Poe, e à preferência por dados temas, como o da identidade, já comentado. Nesse sentido, também outros escritores poderiam ser aproximados por essa via e formariam uma constelação: a dos influenciados por Edgar Allan Poe. Do mesmo modo, seria possível encontrar nas obras desses artistas pontos em comum que os aproximariam entre si, pela influência do mestre Poe. Como é possível notar, segundo Borges "cada escritor crea a sus precursores" no sentido de que, ao ler um determinado escritor, o leitor pode lembrar e identificar o tom, o estilo ou outro aspecto presente num dado escritor. Essa rememoração estabelece uma relação importante entre os escritores por meio do ato de leitura. No caso específico de Machado de Assis e Cortázar, o grande ponto que os aproxima é a influência reconhecida de Poe, além de ter se dedicado à tradução de obras do escritor estadunidense em alguma etapa de suas vidas. Esse diferencial é importante, quiçá outros escritores reconheçam a influência de Poe, mas jamais se dedicaram à tradução de textos do escritor estadunidense. Haveria, então, a possibilidade de criar constelações com diferenciais bem estabelecidos.

De todo o exposto, depreende-se que o papel de revelar os parentescos entre escritores cabe, muitas vezes, aos leitores. E essa é, precisamente, a idéia subjacente no ensaio borgeano: a tarefa da leitura, empreendida como atividade vital, é capaz de revelar que a literatura é, como já dizia Borges no ensaio "La flor de Coleridge", um só e grande texto, escrito por um único espírito espalhado em infinitas mãos.

\section{Bibliografia:}

ALAZRAKI, Jaime. ¿Qué es lo neofantástico? In: ROAS, David (Org.). Teorías de lo fantástico. Madrid: Arco/Libros, 2001.

BENJAMIN, Walter. A tarefa-renúncia do tradutor. In: HEIDERMANN, W. (Org). Clássicos da teoria da tradução. Florianópolis: UFSC, Núcleo de Tradução, 2001. BORGES, Jorge Luis. Kafka y sus precursores. Otras inquisiciones. Madrid: Alianza, 2007.

. La flor de Coleridge. Otras inquisiciones. Madrid: Alianza, 2007. . Las ruinas circulares. Ficciones. Madrid: Alianza, 1997.

. Las versiones homéricas. Obras completas 1923-1949. Buenos Aires: Emecé, 1994. 
CHEVAliER, Jean; GHEERBRANT, Alain. Espelho. Dicionário de símbolos. Mitos, sonhos, costumes, gestos, formas, figuras, cores, números. Trad. Vera da Costa e Silva e outros. $2^{a}$ ed. Rio de Janeiro: José Olympio, 1989.

CORTÁZAR, Julio. Alguns aspectos do conto. Valise de cronópio. $2^{\text {a }}$ ed. São Paulo: Perspectiva, 1993.

Do conto breve e seus arredores. Valise de cronópio. $2^{\mathrm{a}}$ ed. São Paulo: Perspectiva, 1993.

. Poe: o poeta, o narrador e o crítico. Valise de cronópio. $2^{\mathrm{a}}$ ed. São Paulo: Perspectiva, 1993.

. Casa tomada. Cuentos completos I. Madrid: Alfaguara, 1994.

. Distante espejo. Cuentos completos I. Madrid: Alfaguara, 1994.

. Las babas del diablo. Cuentos completos I. Madrid: Alfaguara, 1994.

- Manuscrito hallado en un bolsillo. Cuentos completos II. Madrid: Alfaguara, 1994.

CUNHA, Patrícia L. F. Machado de Assis: um escritor na capital dos trópicos. Porto Alegre: IEL; Editora Unisinos, 1998.

GUILLÉN, C. A estética do estudo de influências em literatura comparada. In: COUTINHO, E. F.; CARVALHAL, T. F. (orgs.). Literatura comparada: textos fundadores. Rio de Janeiro: Rocco, 1994.

JAKFALVI, Susana (ed.). Las babas del diablo. In: CORTÁZAR, Julio. Las armas secretas. $11^{\mathrm{a}}$ ed. Madrid: Cátedra, 1992.

MACHADO DE ASSIS, Joaquim Maria. Advertência de Várias Histórias. Obra completa II. Rio de Janeiro: Nova Aguilar, 1992.

. A causa secreta. Obra completa II. Rio de Janeiro: Nova Aguilar, 1992.

- Memórias póstumas de Brás Cubas. Obra completa I. Rio de Janeiro: Nova Aguilar, 1992.

. O enfermeiro. Obra completa II. Rio de Janeiro: Nova Aguilar, 1992.

. O espelho. Obra completa II. Rio de Janeiro: Nova Aguilar, 1992.

MAGALHÃES JUNIOR, R. (org.). Sem olhos. Contos fantásticos de Machado de Assis. Rio de Janeiro: Edições Bloch, 1973.

(org.). Um esqueleto. Contos fantásticos de Machado de Assis. Rio de Janeiro: Edições Bloch, 1973.

MARTÍN TAFFAREL, Teresa. El tejido del cuento. El tejido del cuento. Barcelona: Octaedro, 2001. 
. De la transmisión oral al cuento literario. El tejido del cuento. Barcelona: Octaedro, 2001.

OMIL, Alba; PIEROLA, Raul A. El cuento y sus claves. Buenos Aires: Nova, s.d. POE, Edgar Allan. A Filosofia da composição. Poemas e ensaios. 3a ed. rev. São Paulo: Globo, 1999.

A queda do solar de Usher. Ficção completa, poesias e ensaios. Rio de Janeiro: Nova Aguiar, 2001.

- Manuscrito encontrado numa garrafa. Fiç̧ão completa, poesias e ensaios. Rio de Janeiro: Nova Aguiar, 2001.

O barril do Amontillado. Fiç̧ão completa, poesias e ensaios. Rio de Janeiro: Nova Aguiar, 2001.

- O coração denunciador. Fiç̧ão completa, poesias e ensaios. Rio de Janeiro: Nova Aguiar, 2001.

TODOROV, Tzvetan. O estranho e o maravilhoso. Introdução à literatura fantástica. $2^{\mathrm{a}}$ ed. Trad. Maria Clara Correa Castello. São Paulo: Perspectiva, 2003.

\section{Title:}

Edgar Allan Poe, Machado de Assis, and Julio Cortázar: Three Views in Conjunction on the Short Story

\section{Abstract:}

Based on the essay "Kafka y sus precursores," by Jorge Luis Borges (1899$1986)$, the present essay looks for coinciding views from Edgar Allan Poe (18091849), Machado de Assis (1839-1908), and Julio Cortázar (1914-1984) on that literary genre. A possible connection between the three writers, regarded as masters of the short story, is suggested having the Borgean essay as a starting point, while emphasizing the similarities of their views on what guides the artistic elaboration of the short stories. The confirmed relationship between Poe and Machado de Assis, and between Poe and Cortázar are emphasized, opening a door to the possibility of also thinking of a close relationship between Machado de Assis and Cortázar.

\section{Keywords:}

Short story; Compared Literature, Edgar Allan Poe, Jorge Luis Borges, Julio Cortázar 